\title{
Race and Revolution at Bwa Kayiman
}

Robbie Shilliam ${ }^{1}$

Queen Mary University of London

Forthcoming in Millennium (2017)

\author{
Sanble Iwa yo \\ Nan Bwa Kayiman nou ye \\ Nou tande fizi tire \\ Apre Bondye \\ Se nou se'l ki chèf la ye \\ Apre Bondye \\ Se nou chèf \\ Let us gather our divinities \\ We are in Bois Caiman \\ We hear the rifles fire \\ After God \\ We are the only chiefs here \\ After God \\ We are the chiefs ${ }^{2}$
}

Sunday $14^{\text {th }}$ August 1791, and at least one hundred workers from across Plaine du Nord parish meet at the large Lenormand de Mézy estate. ${ }^{3}$ These coachmen, commandeurs (drivers) and personal servants of the white plantation owners of St Domingue have been convening with some regularity. Unbeknown to massa, and in conjunction with the maroons of the hinterlands, they have been planning a large insurrection. This particular Sunday is auspicious. It happens to be the eve of the annual celebration of Ezili Kawoulo, a /wa (spiritual agent) who is the patron of secret societies.

\footnotetext{
${ }^{1}$ Sincere thanks to Rachel Beavoir-Dominique and Patrick Bellegarde-Smith for their help, as well as to Alanna Lockward, Gurminder K. Bhambra and Clive Gabay for comments. I learned a great deal from presenting this paper to a joint seminar of Sociology, Africana Studies, Political Science and the Arrighi Center for Global Studies at Johns Hopkins University, and to the Philosophy Society at Brighton University. I am also thankful for the helpful comments of two referees. Big ups to the editors for their professionalism, support and openness.

${ }^{2}$ An elderely Haitian sings this traditional song to Rachel Beauvoir-Dominique during fieldwork in 1999; see "The Social Value of Voodoo Throughout History: Slavery, Migrations and Solidarity," Museum International 62, no. 4 (2010): 99-105.

${ }^{3}$ The account given here is synthesised from Bob Corbett, Daniel Simidor, and Rachel Beauvoir-Dominique, "The Bois Caiman Ceremony: Fact or Myth," 2002, http://faculty.webster.edu/corbetre/haiti/history/revolution/caiman.htm; Rachel Beauvoir-Dominique and Eddy Lùbin, "Investigations Autour Du Site Historique Du Bois Caiman: Rapport" (Cap-Haitien: ISPAN, 2000); Kate Ramsey, The Spirits and the Law: Vodou and Power in Haiti (London: University of Chicago Press, 2011), 43-45; David Patrick Geggus, Haitian Revolutionary Studies (Bloomington: Indiana University Press, 2002), 8192; Carolyn Fick, The Making of Haiti: The Saint Domingue Revolution From Below (Knoxville: University of Tennessee Press, 1990), 91-92.
} 
After some discussion, the date of insurrection is confirmed as the $24^{\text {th }}$ August. For on the following day the colonial assembly will reopen at nearby Cap-Français, and will have brought the political and economic leadership of the Antillean colony together and vulnerable.

A few days later the Chabaud and Gallifet estates are prematurely set ablaze. Upon interrogating the perpetrators, the whites start to realise the significance of the imminent insurrection. The secret is out. So the time to act is now. Amidst a number of responses, Dutty Boukman, a commandeur and coachman of the Clément plantation, hastily convenes a meeting on the following Sunday night, $21^{\text {st }}$ August, at Bwa Kayiman - alligator woods that surround a swamp in the Choiseul and Dustou estates. At this gathering Boukman recites a prayer that he has rehearsed beforehand:

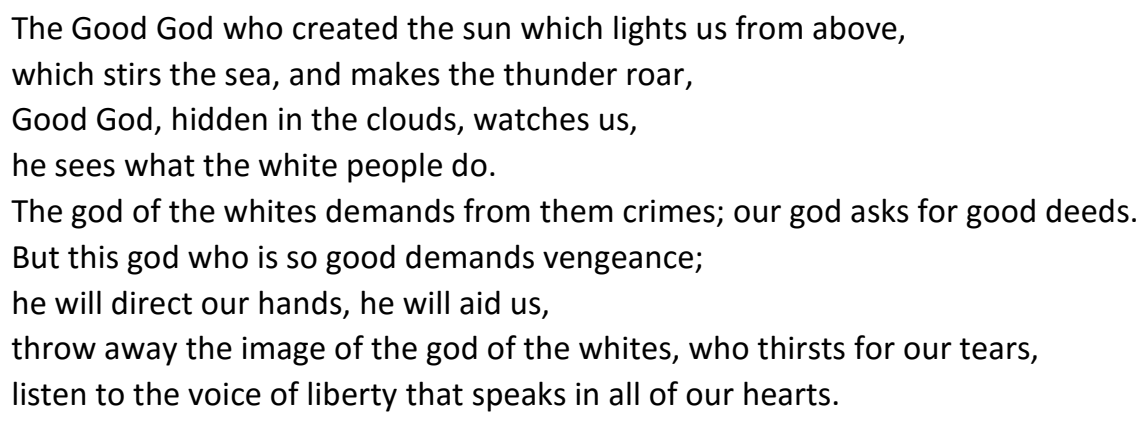

Then Cécile Fatiman, a mambo (female priestess), is ridden by the Iwa Ezili Kawuolo who presides over a blood oath binding all present to liberty or death. In the following week fifteen thousand enslaved peoples join the insurrection and destroy one hundred and eighty-four sugar plantations on the northern plains. It starts from here, in earnest, what comes to be known as the Haitian Revolution. The Iwa gathered with the chiefs, at Bwa Kayiman.

In 1934, CLR James, famous Trinidadian Marxist, writes a play entitled Toussaint L'Ouverture: the story of the only successful slave revolt in history. Two years later it hits theatres in London. Act 1 Scene 2 - and back to Bwa Kayiman. Boukman, (played by Nigerian actor Orlando Martins), reports to the gathering that the "white slaves in France" have started a revolution, killed the slave owners, divided property, and "now there is liberty, equality, fraternity". ${ }^{4} \mathrm{~A}$ man called Toussaint Bréda (played by African-American communist Paul Robeson) addresses the crowd and pleas for them to make a petition to the colonial assembly. Another man, Jean-Jacques Dessalines (played by Guianese actor Robert Adams), emerges rag-tag from the tightly packed bodies, and disagrees: "if we kill the whites we are free". Boukman then recites his prayer and, as he demands his bredrin and sistren to throw away the god of the whites, rips a Christian cross off his neck. The blood sacrifice is passed round. All drink. It is handed to Toussaint. He hesitates... then finally drinks. Dessalines seals the scene by proclaiming "liberty or death!", and all leave the stage, except Toussaint who remains, anguished.

Skip to Scene 3 - a rebel encampment at La Grande-Rivière in 1793. Toussaint sits on his own, in despair. Boukman and other leaders of the militias have just met and prevaricated badly over military and political strategy. ${ }^{5}$ Toussaint laments to the audience: "Oh God! These are them on

\footnotetext{
${ }^{4}$ C. L. R. James, Toussaint Louverture: The Story of the Only Succesful Slave Revolt in History, ed. Christian Hobsbjerg (London: Duke University Press, 2013), 54.

${ }^{5}$ In fact, Boukman was killed much earlier in the Revolution.
} 
whom the fate of the Black race depends. What future is there for us!" He then leafs through the book he holds - a French enlightenment classic, History of the Two Indies by Abbé Raynal. "A courageous chief only is wanted. Where is he? He will come forth, and raise the sacred standard of liberty." ${ }^{\prime 6}$ An epiphany for Toussaint! He mutters with growing comprehension:

Where is he? That great man whom nature owes to her vexed, oppressed and tormented children? Thou has shown me the light, oh God! I shall be that leader. ${ }^{7}$

Thanks to Abbé Raynal and the French luminaires, Toussaint Breda has become Toussaint L'Ouverture - he who makes an opening for his people.

From here on in the play the meaning of the Revolution is framed by CLR through the dynamic held between Toussaint and Dessalines. Toussaint to Dessalines:

Freedom - yes - but freedom is not everything. Dessalines, look at the state of the people. We who live here shall never see Africa again - some of us born here have never seen it. Language we have noneFrench is now our language. We have no education - the little that some of us know we have learnt from France. Those few of us who are Christians follow the French religion ... [O] $f$ the half million negroes in this country three hundred thousand were born in Africa. They can fight, but apart from that they are barbarous savages. ${ }^{8}$

Dessalines to Toussaint:

Education - religion - Toussaint, always the white man's religion, the white man's education ... [l]f we had depended on education and religion we would not ever have got our freedom. Education and religion, but freedom first. ${ }^{9}$

This is the dramatic core to CLR's play. Freedom, made meaningful, must be French (Toussaint); but freedom attained must be anti-French, hence meaningless (Dessalines). Freedom cannot wait; yet the meaning of freedom is waiting for European enlightenment.

CLR's play finally visits Toussaint in a freezing prison cell in the Alps, after having been tricked by Napoleon's forces. CLR renders Toussaint defiant to the bitter end: "You have got rid of one leader. But there are two thousand other leaders to be got rid of as well, and two thousand more when those are killed" ${ }^{10}$ Ultimately CLR places Toussaint's faith with a people-in-arms. The question remains, though, as to what moves them to arms. For what of Boukman and his prayer? Neither Francophile nor Francophobe. Nonetheless, the people at Bwa Kayiman had not waited upon the French, and to them it was still a meaningful action. The Iwa gathered with the chiefs: CLR's dramaturgy renders this assembly meaningless at worst, inconsequential at best.

In Black studies, literary studies, and Atlantic history it is no longer remarkable to claim that, out of all the revolutions in the making of the modern world order, the Haitian was the most radical and remains the most challenging to Euro-Western narratives. The Revolution did what no other did - end slavery - in an age when white Europeans and North Americans spoke of natural rights and freedoms while they remained traffickers and brutal exploiters of African flesh. A similar shift in the

\footnotetext{
${ }^{6}$ Ibid., 69-70.

${ }^{7}$ Ibid., 70.

8 Ibid., 94.

${ }^{9}$ lbid.

10 Ibid., 127.
} 
recognition of the Revolution has been underway in both historical sociology and political theory; ${ }^{11}$ and so too, even, amongst scholars of International Relations. ${ }^{12}$ The stakes at play are significant: to theorise and narrate the Haitian Revolution is to necessarily take part in a struggle over the authorship of global justice and its meanings.

But as we deepen our understandings of the Revolution we must grapple more audaciously with the intellectual strictures that have in various ways "silenced" these struggles of enslaved Africans. ${ }^{13}$ Because race informs these silencings. In order to argue how, exactly, I want to first present three tropes that have been influential to the historiography of the Revolution. I shall not spend time on perhaps the most popular Eurocentric trope, which effectively claims the Haitian revolutionaries as workmen for the universality that was conceived and authored by the French Revolution and European enlightenment thought. ${ }^{14}$ Instead, I will focus on two alternatives.

In the way that I invoke it here, the "creole" trope refers to being born in the Caribbean. More specifically I have in mind the conception of the colonial Caribbean as a "precocious" site of modernity. ${ }^{15}$ This creole trope escapes Eurocentrism in so far as it presents enslaved Africans as (at the very least) collective creators of a modernity that has no prior dialectic to approximate. However, I am concerned most of all with the sociological premises of such a conception that make plantation economies spaces-made-blank: the first premise, that indigenous genocide ensures that there are no extant practices and inhabitations to build upon; the second premise, that enslavement creates radical ruptures with past identities and practices, which then require brand new modes of thinking, being and associating.

Alternatively, there is what I would call the "retention" trope. Here, the dynamics of the Revolution are gleaned through the various cosmologies and practices that peoples carried across the Atlantic, there, in the Americas, to be creatively reiterated, sometimes with indigenous

\footnotetext{
${ }^{11}$ For example Gurminder K. Bhambra, "Undoing the Epistemic Disavowal of the Haitian Revolution: A Contribution to Global Social Thought," Journal of Intercultural Studies 37, no. 1 (January 2, 2016): 1-16; Anthony Bogues, "The Haitian Revolution and the Making of Freedom in Modernity," 2005, http://www.polisci.upenn.edu/programs/theory/bogues.pdf; Susan Buck-Morss, Hegel, Haiti and Universal History (Pittsburgh: University of Pittsburgh Press, 2009); Clinton Hutton, The Logic and Historic Significance of the Haitian Revolution and the Cosmological Roots of Haitian Freedom (Kingston: Arawak, 2007); Neil Roberts, Freedom as Marronage (Chicago, 2015).

${ }^{12}$ For example Tarak Barkawi, Globalization and War (Lanham: Rowman \& Littlefield, 2006), 16-18; Cristian Cantir, "World Society, International Society and the Periphery: British Abolitionists and the Post-Slave State of Haiti in the Early Nineteenth Century," Cambridge Review of International Affairs 0, no. 0 (January 11, 2016): 1-17; Siba N. Grovogui, "Mind, Body and Gut! Elements of a Postcolonial Human Rights Discourse," in Decolonising International Relations, ed. B. Gruffydd Jones (Lanham: Rowman \& Littlefield Publishers, 2006); Robert Shilliam, "What the Haitian Revolution Might Tell Us about Development, Security, and the Politics of Race," Comparative Studies in Society and History 50, no. 03 (July 2008): 778-808.

${ }^{13}$ Michel-Rolph Trouillot, Silencing the Past : Power and the Production of History (Boston: Beacon Press, 1995).

${ }^{14}$ For example Nick Nesbitt, Universal Emancipation: The Haitian Revolution and the Radical Enlightenment (Charlottesville: University of Virginia Press, 2008). For a convincing critique see Bhambra, "Undoing the Epistemic Disavowal of the Haitian Revolution."

${ }^{15}$ See for example Sidney W. Mintz, "Enduring Substances, Trying Theories: The Caribbean Region as Oikoumene," The Journal of the Royal Anthropological Institute 2, no. 2 (1996): 289-311; J. Bernabé, P. Chamoiseau, and R. Confiant, "In Praise of Creoleness," Callaloo 13, no. 4 (1990): 886-909; see also Lorenzo D. Turner, "The Negro's African Past," ed. Melville J. Herskovits, The Journal of Negro Education 11, no. 2 (1942): 185-87.
} 
cosmologies and practices, as they confront plantation slavery. ${ }^{16}$ In practice the distinction between what is "creole" and what is a "retention" might not necessarily be significant or controversial. Historiographically speaking the distinction takes on far more importance. In fine, the retention trope differs subtly but crucially from the creole trope to the extent that it confounds any premise that creole creativity must begin with blank landscapes and blank bodies. Making "blank", we might note, is a historical practice of colonial rule.

CLR's drama sits uneasily between Eurocentrism and an acknowledgement of creole agency, hence the title off his subsequent and tremendously influential book: Black (creole) - Jacobin (French). Much later in his life, CLR would reflect upon his omission of retentions: "for the slave brought himself [sic]; he brought with him the content of his mind, his memory. He thought in the logic and the language of his people. He recognized as socially significant that which he had been taught" ${ }^{17}$ Let us, then, follow through with the elderly CLR's self-critique. For besides the French and their discontents there stand the Iwa, gathered with the chiefs. What are their provenances?

As John Thornton argues, enslaved Africans brought their rich spiritual, cultural and political lives with them as they were forced to cross the Atlantic. By the time of Bwa Kayiman, $50 \%$ of the 500,000 enslaved in St Domingue had arrived in the past three to five years, while roughly two thirds of the general population had been born on the African continent. ${ }^{18}$ Because the trade in human traffic principally covered three major geo-cultural regions on the continent, enslaved Africans in the Americas were often able to translate each-others language and practices. Such re-associations were easier in plantation economies composed of large holdings such as St Domingue. ${ }^{19}$ In fact, the majority of new arrivants to north St Domingue (the vicinity of Bwa Kayiman) had been trafficked from the Kongo region. ${ }^{20}$ This being said, the retention of diverse African cosmologies and practices was not simply a demographic fiat; it was, as Jean Casimir argues, also a result of the relatively late and intense development of St Domingue. This speed, absent of sufficient resources, mitigated against attempts by colonizers and slave-holders to fully "creolize" (and, in the French context Christianize) enslaved Africans. ${ }^{21}$

As well as a focus on new arrivants we must also consider archaeological and oral histories which testify to a long-standing relationship between enslaved Africans and indigenous Taino peoples. ${ }^{22}$ Such relationships were formed in the sixteenth century with the arrival of captives from Senegambia when the entire island was under Spanish rule. In fact some of the sites that became associated with Bwa Kayiman (Bwa, a Kreyol word for wood; Kayiman the Taino word for alligator)

\footnotetext{
${ }^{16}$ In this respect, I have been most influenced by the works of Clinton Hutton, Rachel Beauvoir-Dominique, Patrick Bellegarde-Smith and John Thornton.

${ }^{17}$ CLR James, "The Atlantic Slave-Trade (1970)", in The Future in the Present: Selected Writings (London: Allison \& Busby, 1977), p.243.

18 John Thornton, "I Am the Subject of the King of Congo': African Political Ideology and the Haitian Revolution," Journal of World History 4, no. 2 (1993): 183; Ramsey, The Spirits and the Law, 29.

19 John Thornton, Africa and the Africans in the Making of the Atlantic World (Cambridge: Cambridge University Press, 1998), 187, 198.

${ }^{20}$ Thornton, "King of Congo," 184; John Thornton, "Cannibals, Witches, and Slave Traders in the Atlantic World," The William and Mary Quarterly 60, no. 2 (2003): 290-291.

${ }^{21}$ See Jean Casimir, "Haïti et Ses élites: L'Interminable Dialogue de Sourds," Worlds and Knowledges Otherwise, no. Fall (2008): 1-27.

${ }^{22}$ See Beauvoir-Dominique, "The Social Value of Voodoo"; Rachel Beauvoir-Dominique, "The Rock Images of Haiti: A Living Heritage," in Rock Art of the Caribbean, ed. Michele H. Hayward, Lesley-Gail Atkinson, and Cinquino, Michael A. (Tuscaloosa: University of Alabama Press, 2009), 78-89.
} 
had long been hiding places for the island's indigenous peoples. ${ }^{23}$ The cultivation of shared knowledge of the island's flora and fauna, topography and spiritual agents took place in such hinterland maroon communities where escaped Africans lived with Taino. ${ }^{24}$ Indeed, while over the centuries the vast majority of Taino were annihilated, and while the populations of maroon communities always remained small, the maroon influence on enslaved Africans was deep rooted and significant. Even in the late eighteenth century it was common for enslaved peoples - creole and otherwise - to undertake "petit marronage", that is, a temporary removal of oneself from the plantation so as to visit other plantations and maroon communities..$^{25}$

All these diverse African and indigenous retentions articulated with, against and besides the colonial order. And these articulations provide an alternative cartography with which to find our way to Bwa Kayiman.

It is clear, for instance, that the meeting of August $14^{\text {th }}$ was attended mostly by the relatively mobile "elite" of the enslaved population. ${ }^{26}$ On the plantations, creoles - enslaved peoples born in St Domingue - easily predominated in positions of relative power as opposed to the majority Africanborn field hands. ${ }^{27}$ Certainly, the organisational acuity of creole elites in their work-roles as coachmen, commandeurs etc. formed one key factor in mobilizing for the Revolution. Yet field hands were not lacking in their own abilities. They often arrived already possessing martial skills, and, as I have noted, arrivants were willing and able to re-assemble their prior associations as nanchons (nations) - e.g. as Rada, Dahomey, Nago, Gede, Kongo, etc. ${ }^{28}$ They did so both within and across plantations and even elected "kings" and "queens" to this effect. Many also spoke primarily in African languages rather than Kreyol. ${ }^{29}$ Nanchons therefore intersected with but also cut-across the divisions of plantation labour whose main authorities were creole "elites". ${ }^{30}$ Then to these intersections we must of course add the maroons who, despite their communal autonomy, were always tenuously and influentially connected to the plantation system.

It is difficult to carve out, from the cartography that I have just presented, a "creole" space sui generis to the Caribbean and not already integrated deeply into indigenous and African retentions of various kinds. Nonetheless, the urge to diminish these retentions and/or creolise their actors is marked in much of the historiography of the Revolution. Take, for instance, CLR's two key protagonists. Despite his acclaimed Francophilia, Toussaint was in fact accomplished in relating to the leaders of militias through the logics and mores of African retentions. ${ }^{31}$ Then there is the Francophobe Dessalines, almost always described as a "creole", like Toussaint. Yet, as Deborah Jenson demonstrates, contemporaneous accounts of Dessalines unanimously described him as African-born. ${ }^{32}$ It is only with the mid nineteenth century writings of Haitian historian Thomas

\footnotetext{
${ }^{23}$ See Rachel Beauvoir-Dominique, "Reclaiming Indigenous Heritage in Haiti: Our Taino Culture Is Alive and Well," Taino Legacies, April 2016, http://www.tainolegacies.com/154087477.

${ }^{24}$ See for instance Beauvoir-Dominique, "Rock Images of Haiti."

25 See in general Fick, The Making of Haiti, 51-57; Thornton, Africa and the Africans, 272-293.

${ }^{26}$ Fick, The Making of Haiti, 95.

27 Thornton, "King of Congo," 199.

${ }^{28}$ Beauvoir-Dominique and Lùbin, "Investigations Autour Du Site Historique Du Bois Caiman," 45.

29 Thornton, "King of Congo," 204.

${ }^{30}$ See for example ibid., 201; Deborah Jenson, "Jean-Jacques Dessalines and the African Character of the Haitian Revolution," The William and Mary Quarterly 69, no. 3 (2012): 625.

${ }^{31}$ Madison Smartt Bell, "Toussaint Between Two Worlds," Journal of Haitian Studies 11, no. 2 (2005): 41.

32 "Jean-Jacques Dessalines."
} 
Madiou, an enthusiast of French romantic historiography, that Dessalines loses his African retention and becomes creole.

I want to take CLR's drama as symptomatic of the problem that I am alluding to. CLR collapses the stakes at play in the Revolution to a choice between meaningful French tutelage (Toussaint) or meaningless creole independence (Dessalines). This choice makes absent the complex and rich landscape of African and indigenous retentions that I have sketched out. Above all, it absents, as effective agents of revolution, Ezile Kawoulo and the other I $w a-$ those spiritual agents who gather with the chiefs at Bwa Kayiman. Race is fundamental to this making absent.

I have argued elsewhere that colonial science seeks to segregate peoples from their lands, their pasts, their ancestors, spirits and agencies. ${ }^{33}$ In fact, I have claimed that the deepest cut made by colonial science lies in the attempt to cleave the manifest realm of colonial rule from the uncolonized spiritual hinterlands. For there, in the hinterlands, lie the deepest retentions that threaten colonial order. I cannot rehearse the argument in full here, but I do need to broach some of its elements in order to explain the implication of race in the historiographical absenting of the /wa.

A good place to start is Georg Hegel's racist world history. Hegel narrates the movement of spirit towards a form of religious association - the Protestantism of small German states - that enables universal reason to be profanely constitutionalised. ${ }^{34}$ In this movement, as is well known, Asia is left behind as childhood and Africa is not even considered competent to take part in the human drama. Certainly, Hegel considers Protestantism to be one step more progressive than the French Catholicism practiced in the Antilles. Still, the point I want to make is that Hegel's narrative is exemplary of the movement authorised by colonial science of the racist world spirit - reason towards Western European i.e. white Christianity.

There is more. With this movement already established, colonial science subsequently shifts in the nineteenth century to evaluate the status of civilization solely and directly via the arrangements of civic law. These arrangements, gleaned via the applied (and not solely speculative) anthropologies of especially Edward Burnett Tylor and Lewis Henry Morgan, are taken to demonstrate cultural competency in the ability to exercise reason. Reason is now profaned in terms of explication and appearance, as Spirit no longer authorises evaluation. And so only profane reason is considered effective in the driving forward of the human drama. In short, colonial science becomes "real" Science.

Nevertheless, contemporary discussions over political theology seem to disturb these sedimented premises of colonial science. Recognising the disenchanted nature of modernity, some political theorists have suggested that any retrieval of contemporary ethics in the West will require a re-investment in faith of some sort. An anxiety has arisen over the possibility for such a reinvestment to be undertaken without undermining a core commitment to the strictly profane provenance of modern reason. ${ }^{35}$ Still, as Nelson Maldonado-Torres suggests, this "post-secular" anxiety is overwhelmingly expressed by reference to theological debates in white Christianity and, I

\footnotetext{
${ }^{33}$ Robbie Shilliam, The Black Pacific: Anticolonial Struggles and Oceanic Connections (London: Bloomsbury Academic, 2015).

${ }^{34}$ See Robbie Shilliam, German Thought and International Relations: The Rise and Fall of a Liberal Project (New York: Palgrave Macmillan, 2009), 112-113.

${ }^{35}$ See for example Simon Critchley, The Faith of the Faithless: Experiments in Political Theology (London: Verso Books, 2012); Peter E. Gordon, "Critical Theory between the Sacred and the Profane," Constellations Firstview (2016): 1-26.
} 
would add, specifically German controversies over the response of the "Confessing Church" to Nazism. ${ }^{36}$ However, similarly intense and more contemporary controversies over Black power and Black theology are hardly ever referenced, despite also taking place within the Christian ecumene. ${ }^{37}$

I would argue that this exclusion reveals the sedimented nature of racial hierarchies and exclusions in colonial science that lead back to Hegel: at its purest and most competent, reason is profane but, failing that, reason finds in white Christianity a protective provenance. Now, what is the science of apprehending the Iwa? It is Vodou. But Vodou is already twice disavowed by colonial science: first as religion, then second as African - Black - superstition.

Perhaps because of this double exorcism, Vodou has always been considered a dangerous presence by colonial forces. Of especial importance, in this regard, is the US occupation of Haiti in 1915 (and of the Dominican Republic less than one year later). US military officials (correctly) surmised that Vodou was directly implicated in the armed resistance to their occupation and so singled out for special enforcement articles in the Haitian Code Pénal which prohibited the making of les sortilèges (spells). ${ }^{38}$ At the same time, the occupation gave rise to an aesthetic transmission of "voodoo" in the form of a negro primitivism that threatened to infect the wider (white) world. In this way, Victor Halperin's 1932 film, White Zombie, announced the racially-eroticized "zombie" genre to posterity. ${ }^{39}$ Black spirit had come to defile Hegel's luminous West.

The equivalent to this aesthetic damnation of Vodou can be found in much historiography on Bwa Kayiman whereby Vodou, even if recognized, is often denied any effective influence in the Revolution itself. Take, for instance, the work of David Geggus, an influential revisionist historian. Geggus presumes - and it is indeed a presumption - that the first meeting of August $14^{\text {th }}$ is the properly-political meeting of creoles who have been influenced by profane French events; the second meeting, one week later, is in contrast merely a "religious" Vodou ceremony. ${ }^{40}$ The Iwa are not effective agents of (world) revolution, they are epiphenomenal. It is only the chiefs who really gather at Bwa Kayiman.

But what if we were to take seriously the above provocation that the categorical segregation of primitive/superstitious/(black) unreason and civilized/Christian/(white) reason is an artefact of colonial science. Not a transparent premise of science per se, might this segregation be part of a political project to cleave the manifest realm of colonial rule from the uncolonized spiritual hinterlands? With this provocation I am asking you to take a step sideways to colonial science. Here

\footnotetext{
${ }^{36}$ Nelson Maldonado-Torres, "Secularism and Religion in the Modern/Colonial World-System: From Secular Postcoloniality to Postsecular Transmodernity," in Coloniality at Large: Latin America and the Postcolonial Debate, ed. Mabel Moraña, Enrique Dussel, and Carlos A. Jáuregui (Durham: Duke University Press, 2008), 360-84.

37 See for example, J. Deotis Roberts, A Black Political Theology (Philadelphia: Westminster Press, 1974); Delores S. Williams, "Womanist Theology: Black Women's Voices (1986)", in L. Phillips (ed.), The Womanist Reader (London: Routledge, 2006), 117-125

${ }^{38}$ Ramsey, The Spirits and the Law, 120.

${ }^{39}$ See for example Kyle Bishop, "The Sub-Subaltern Monster: Imperialist Hegemony and the Cinematic Voodoo Zombie," The Journal of American Culture 31, no. 2 (June 1, 2008): 141-52.

${ }^{40}$ Geggus, Haitian Revolutionary Studies, 48; and see critiques by Hutton, Significance of the Haitian Revolution, 79, 95-97; and Rachel Beauvoir-Dominique in Corbett, Simidor, and Beauvoir-Dominique, "The Bois Caiman Ceremony."
} 
is a compass bearing from the testimony of Maya Deren, Ukranian-born choreographer, avant-garde film-maker, and witness of Vodou in post-war Haiti:

Demur, if you will, that all this is merely a reference to a man's intellectual powers. Explain that it is the "imagination" which makes him capable of conceiving beyond the reality which he knows, and that this is compounded of memories. Speak of "idealism" as source of his willingness to undergo ordeal on behalf of creative, non-material achievement. Insist that in foregoing immediate reward he seeks historical position. Add, even, that such values are engendered by the influence of father, the love of mother, the praise of men. List all those intellectual and moral qualities - vision, inspiration, imagination - which most distinguish the poet, the philosopher, the scientist; catalogue them, name them, count and differentiate and "explain" their origins, their operation, mechanisms and motivations. The Haitian will not dispute you. When you have finished, he might shrug his shoulders, saying simply, in Creole: "All that, we call 'to have loa [/wa - spiritual agents].'41

So, with Deren I want to propose that Vodou is not the antithesis of but merely other-wise to colonial science - another kind of reasoning that calls forth the Iwa.

\section{From where?}

For Vodou adepts, Ginen (from Africa) certainly does not invoke the Hegelian condition of non-being untouched by world spirit, i.e. outside of the time and space of human drama. Rather, Gine references a forested island - Grand Bois d'ilet - that exists beneath the ocean and which is home to the Iwa who live in its city, Ville-aux-Camps. ${ }^{42}$ Moreover, the nanchons (nations) of Iwa who comprise this population (including Taino) are not the hypostatised "tribes" of colonial anthropology but, alternatively, delineations of various qualities of the human experience of the cosmos. Hence the oft-vaunted claim by adepts that "we are the children of Guinea" ${ }^{43}$ cannot be read as naïve colonial geography or romantic atavism but rather as a cosmological positioning of African and indigenous retentions.

Let us follow, in this regard, the Vodou cosmogram of the cross(roads). Two sets of coordinates overlap - the four cardinal points of the manifest world, and the intersection of that world with the world of spiritual agents. ${ }^{44}$ With regards to the latter coordinates, the horizontal line marks the realm of the human living while the vertical line marks the medium of communication between them and the Iwa. The bottom of the cross plunges into the cosmic waters of Gine where the Iwa live in Ville-aux-Camps on the island of Grand Bois. The point where the lines intersect is where humans and /wa meet. ${ }^{45}$ In this way the cosmogram of the cross(roads) rules out the existence of a profanely-natural domain that stands in categorical opposition to a super-natural domain. Colonial science requires the category of the super-natural. Vodou renders such a category as senseless.

That the domains of the Iwa and humans can intersect is due, precisely, to Vodou's investment in the cosmological conceit of seminal relationality rather than fidelity towards the principle of categorical segregation embraced by colonial science. Seminal, in this sense, infers that the entity carries within itself the relations through which it was generated. Seminality is enacted, for example, in the Vodou ceremony that sees the hougan (priest) emerging out of a sacred chamber

\footnotetext{
${ }^{41}$ Maya Deren, Divine Horsemen: The Living Gods of Haiti (New Paltz: McPherson, 1983), 248-249.

${ }^{42}$ McGee, "Constructing Africa," 31; Deren, Divine Horsemen, 36.

${ }^{43}$ Serge Larose, "The Meaning of Africa in Haitian Vodu," in Symbols and Sentiments: Cross-Cultural Studies in Symbolism, ed. I.M. Lewis (London: Academic Press, 1977), 100.

${ }^{44}$ Leslie Gerald Desmangles, "African Interpretations of the Christian Cross in Vodun," Sociological Analysis 38, no. 1 (13-24): 43-46.

${ }^{45}$ Ibid., 45; Deren, Divine Horsemen, 35.
} 
in a backward motion, orienting the congregation to the first human and ultimately to the (distant) godhead, the source of all cosmic agency and relation. ${ }^{46}$

The Iwa manifest seminal relationality. Let us briefly consider a few of them. Legba, the agent of intercession between the I $w a$ and humans, is always invoked first in any order of service in order to "open the gates so that we may pass through" ${ }^{47}$ Following Legba is Loco, the ancestral priest of the Taino who is introduced to enslaved Africans in maroon communities as the agent of knowledge, medicine and wisdom. ${ }^{48}$ Loco is accompanied by Ayizan, the female guardian of the place of one's spiritual birth. ${ }^{49}$ These agents provide the dignity that makes human life meaningful. ${ }^{50}$ Les Marassa, the first ancestors, are female and male twins who express the-divinity-that-composesthe-human and the-humanity-that-composes-the-divine. ${ }^{51}$ Erzulie Fréda Dahomey, a key feminine principle, provides human beings with the capacity to be sublime, that is, "to conceive beyond reality, to desire beyond adequacy, to create beyond need". ${ }^{52}$

Contra colonial science, Vodou apprehends the uncolonized spiritual hinterlands as effectively connected, through the I $w a$, to struggles over the colonized manifest domain. This means that the pursuit of justice is cosmically seminal in its dimensions and consistency: humans can/must gain useful knowledge and agency through the Iwa to redress their manifest situation. One cannot, then, gather with the Iwa at Bwa Kayiman under the presumption that a luminous white humanity must be contrasted to Black sub-humanity, that in claiming nature white society must dispel the black super-natural, and that only profaned reason should explain the Haitian Revolution. The Eurocentric trope of the Revolution depends upon these segregations; the creole trope accepts some of these segregations as existentially given; while the logic of the retention trope might move us to inhabit a cosmos of seminal relationality.

We have now oriented ourselves towards the gathering of the Iwa and the chiefs. Standing in their presence, let us come to terms with the ethos of their relationship.

For this purpose, it is useful to recall Dutty Boukman's prayer at Bwa Kayiman. Although first committed to text over thirty years later there is evidence that the prayer was generally known and recited during the early days of the Revolution. ${ }^{53}$ As Rachel Beauvoir-Dominique notes, the prayer is defined by a crucial shift in register from a "pastoral" and distant god who is "hidden in the clouds" to two engaged spiritual agents of the whites and the Blacks. ${ }^{54}$ The former demands crimes of his subjects; the latter demands justice and he will "direct our hands" and "aid us". ${ }^{55}$ In Vodou, Bondye (bon dieu - good god) is a remote, immaterial creating force and only works through intermediaries, who are first and foremost the residents of Ville-aux-Camps. ${ }^{56}$ To different degrees, then, the Iwa

\footnotetext{
${ }^{46}$ Desmangles, "The Christian Cross in Vodun," 20.

47 Deren, Divine Horsemen, 96; see also Desmangles, "The Christian Cross in Vodun," 42.

${ }^{48}$ Hurston, "Tell My Horse," 394; Beauvoir-Dominique, "Reclaiming Indigenous Heritage."

${ }^{49}$ Deren, Divine Horsemen, 147-148.

50 Ibid., 150.

${ }^{51}$ See ibid., 27, 38.

52 Ibid., 138.

${ }^{53}$ Fick, The Making of Haiti, 104.

${ }^{54}$ Beauvoir-Dominique and Lùbin, "Investigations Autour Du Site Historique Du Bois Caiman," 9.

${ }^{55}$ See especially Celucien Joseph, "The Rhetoric of Prayer: Dutty Boukman, the Discourse of 'Freedom from Below' and the Politics of God," Journal of Race, Ethnicity and Religion 2, no. 9 (2011): 1-33.

${ }^{56}$ Ramsey, The Spirits and the Law, 7; Krista Tippet and Patrick Bellegarde-Smith, "Speaking of Faith: Living Vodou," Journal of Haitian Studies 14, no. 2 (2008): 148.
} 
must engage themselves in human affairs. ${ }^{57}$ In fact, while Vodou adepts serve their Iwa, the Iwa is likewise expected to serve the living - to be manifestly useful..$^{58}$ In cognate fashion Boukman's prayer announces that justice is not super-natural to enslaved peoples - it is not a case of waiting for heaven to see Jesus. Rather, justice must be pursued immediately through the mediation of spiritual agents $(/ w a)$ in the domain of human beings.

Remember, also, that in Boukman's prayer it is not white people who are essentially evil, rather, injustice results from the practical consequences of mediation with their spiritual agent. Similarly, it is not black people who are essentially good, rather, mediation with their spiritual agent compels them to seek justice. Mediation is therefore fundamental to the ethos of Vodou because every entity manifests through seminal relations, especially the relationality between the world of humans and the world of the /wa..$^{59}$

This ethos of mediation jars against the "subject" of ethics presumed by much Western political philosophy, i.e. an ontologically sealed self whose "inner" life must always try and (subsequently) encounter/recognize outside of itself. ${ }^{60}$ Alternatively, Vodou conceives of the mait tèt (master of the head) not as a "sovereign self" but as a particular /wa, often - but not always inherited through family, and who at some point in adult life becomes "fixed" as a regular aspect of consciousness. ${ }^{61}$ As Roberto Strongman convincingly argues, such an articulation of consciousness suggests that the self is spiritually and communally "distributed". I would add that the distributed character of the self is made possible by its seminally relational nature.

This Vodou self owes much to the retention of Aja cosmologies wherein human life is comprised of the body and two shadows. In Vodou, alongside the flesh, bone and sinew of the body, there exists two shadows of animation known as the tibonanj (ti bon anj-small good angel) and the gwobonanj (gwo bon anj - big good angel). ${ }^{62}$ The tibonanj can be apprehended as an "objective" principle. ${ }^{63} \mathrm{It}$ is impersonal, detached from the pressing requirements of corporeal need and affect, and thus a cosmological constant in so far as it is the seat of morality and a "spiritual reserve tank". The gwobonanj can be apprehended as "consciousness". It is constitutive of emotions, sentiments and, unlike the tibonanj, is directly affected by the requirements of corporeal life. The gwobonanj is cruder - heavier - than the tibonanj, but nonetheless the seat of agency. The gwobonanj is that which must be made to regulate "collective morality in action". ${ }^{64}$

While the tibonanj dissipates nine days after corporeal death, the gwobonanj is separable from the corporeal body even during corporeal life. ${ }^{65}$ This malleability is precisely what allows for the infamous act of "possession", which Vodou adepts alternatively describe as being "mounted" by a Iwa (spiritual agent) just as a horse is mounted by a rider. In this process the Iwa-usually the mait tèt (master of the head) - displaces the gwobonanj and takes its seat. (The tibonanj remains with the

\footnotetext{
57 Tippet and Bellegarde-Smith, "Speaking of Faith," 152,154.

58 Deren, Divine Horsemen, 28, 74.

${ }^{59}$ Claudine Michel, Patrick Bellegarde-Smith, and Marlene Racine-Toussaint, "From the Horses' Mouths: Women's Words/ Women's Worlds," in Haitian Vodou: Spirit, Myth, and Reality, ed. Patrick Bellegarde-Smith and Claudine Michel (Bloomington: Indiana University Press, 2006), 730-734.

60 "Transcorporeality in Vodou," 5-7; see also my Black Pacific.

${ }^{61}$ Larose, "The Meaning of Africa," 94.

62 see Strongman, "Transcorporeality in Vodou," 9-10; Montilus, "Vodun and Social Transformation," 2.

${ }^{63}$ Deren, Divine Horsemen, 26-30, 44; Strongman, "Transcorporeality in Vodou," 10-11; Larose, "The Meaning of Africa," 92-94.

${ }^{64}$ Deren, Divine Horsemen, 27.

65 Strongman, "Transcorporeality in Vodou," 23; Larose, "The Meaning of Africa," 93.
} 
body, else death would occur). Due to the absence of the gwobonanj the "horse" has no consciousness of the rider's actions and communications during this period. ${ }^{66}$

I want to insist on the importance of this last point. The mounting of the horse by Iwa is not adequately explained through social-scientific concepts such as representation, performativity, mimesis, transference, or false consciousness, all of which work with some notion of the profane, enclosed "subject". But with the seminally-relational self it is, precisely, the Iwa who are speaking and doing in the world of human beings. ${ }^{67}$ Through mediation with human being, the Iwa, organized as nanchons (nations) that express various qualities of human existence, channel into the manifest world diverse cosmic forces - love, violence, prescience, mercy, vengeance, determination, death, greed, renewal, sustenance, beauty - all of which eventually and impersonally work for bondye - the good god.

You can consider this ontological conceit from another angle, if you wish. A maleficent practitioner can remove a living person's gwobonanj in order to command a body (corps cadaver) in the pursuit of personal gain. This is the zombie of Hollywood fame; the "slave" of St Domingue. In this respect, what kind of power could a "slave" - a profane thing that simply produces things for humans - ever have possessed? Where would its inspiration and knowledge come from? What would move it, except for the biological nerve system and massa's whip? Mediating with the Iwa allow the profanely enslaved to channel forces from the spiritual hinterlands that bypass and exceed the control of their downpressors. ${ }^{68}$ The community is re-sanctified by gaining cosmic force and direction in the pursuit of justice: the Iwa and the chiefs, moved to arms, gathered at Bwa Kayiman.

I have argued that the ethos of the relationship between Iwa and humans is predicated upon the mediation of cosmic power. And now I wish to inquire more specifically into the ethics of regulating cosmic power. For this purpose, it is instructive to reflect on a ritual chant of enslaved Kongo peoples witnessed in St Domingue by Moreau de Saint-Méry, a white creole lawyer, and recorded just a few years before Bwa Kayiman:

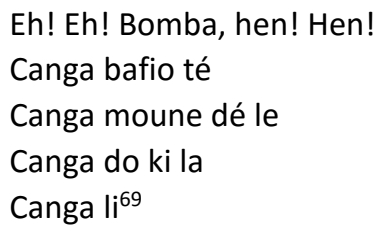

The popular translation of this chant, one reproduced by CLR James, is: "we swear to destroy the whites and all that they possess; let us die rather than fail to keep this vow". 70 "Wildly inaccurate", this translation reproduces the Manichean violence authored by colonial science. ${ }^{71}$ But glossed by an expert in the Kikongo language, the chant unfolds a much more enigmatic meaning:

Eh! Eh! Mbomba hen! hen!

Hold back the black men

Hold back the white man

\footnotetext{
${ }^{66}$ Deren, Divine Horsemen, 29; Strongman, "Transcorporeality in Vodou," 12; Montilus, "Vodun and Social Transformation," 3; Ramsey, The Spirits and the Law, 8-9; Hurston, "Tell My Horse," 43.

${ }^{67}$ See Deren, Divine Horsemen, 194.

68 See Montilus, "Vodun and Social Transformation," 3.

69 Fick, The Making of Haiti, 57.

70 Ibid.; Thornton, "King of Congo," 211.

${ }^{71}$ Fick, The Making of Haiti, 57.
} 
Hold back that witch

Hold them. ${ }^{72}$

The key verb - kanga - has multiple and overlapping meanings in eighteenth century Kikongo. In all dialects kanga can be glossed as to hold back, stop or bind. I want to work specifically with the last meaning because the importance of binding is retained in Vodou practice whereby the tying of an object is considered a means to concentrate cosmic power - for example in charms, amulets or within the body itself. ${ }^{73}$ It is also important to note that, amongst Christian Kikongo speakers, kanga would also infer salvation - to protect, deliver. ${ }^{74}$ (The Kingdom of Kongo had formally indigenised Christianity in the early $16^{\text {th }}$ century). Therefore, to bind (kanga) infers, all at the same time, to concentrate power/stop/protect/deliver.

But who are to be bound and by whose authority? The latter is clear: Mbomba references a Kikongo name for the (distant) creating force, consonant with Bondye. ${ }^{75}$ What of the others? The bafioti ("black men") reference, specifically, enslaved Africans. ${ }^{76}$ Moune is Kreyol for person, referencing the Kikongo word muntu, and in this context, following the previous line, infers a white man. The ndoki ("witch") requires a little more explication.

Peoples in the lands that spoke Kikongo tended to assume that maleficent spiritual science (I prefer not to use the term "witchcraft") was undertaken by secret societies in the pursuit of individual gain and in opposition to the open practice of spiritual science directed towards personal healing or collective welfare. ${ }^{77}$ Consonant to Boukman's prayer, the kanga chant does not racialize the ndoki ("witch") as white. However, merchants were especially vulnerable to the charge of maleficent spiritual science due to their mobility and individualistic behaviour. ${ }^{78}$ Certainly, by the late eighteenth century all those involved in the trade in Africans in the centre-west of the continent were considered to be involved in - more accurately, perhaps, suffering from - maleficent spiritual science. ${ }^{79}$

We can therefore glean in the kanga chant a cosmic imperative that all must be bound to deliver justice from enslavement and to be delivered from its evil. Being "bound" in this way connotes that both enslaved and enslavers must be accountable for the power that they wield and the actions that they pursue, whether they are against or even for salvation. To be clear on this point: at Bwa Kayiman, the righteous cosmic power exercised by enslaved Africans through their mediation with /wa must also be bound, that is, ethically controlled.

But how, exactly, are the Iwa implicated in this injunction to bind power, even righteous power? To address this question, I want to discuss an abiding and famous distinction made in the

\footnotetext{
72 Thornton, “King of Congo," 211.

73 Terry Rey and Karen Richman, "The Somatics of Syncretism: Tying Body and Soul in Haitian Religion," Studies in Religion 39, no. 3 (2010): 389.

74 Ibid., 212.

75 Ibid., 192-194; Hutton, Significance of the Haitian Revolution, 89-108.

${ }^{76}$ Thornton convincingly shows that Fick's translation of Bafioti as a tribe of African enslavers is incorrect. See Fick, The Making of Haiti, 58; Thornton, "King of Congo," 212.

${ }_{77}$ Maureen Warner-Lewis, Central Africa in the Caribbean: Transcending Time, Transforming Cultures (Kingston Jamaica: University of West Indies Press, 2003), 139.

78 Thornton, “Cannibals, Witches," 282.

79 See for example John M Janzen, Lemba,1650-1930: A Drum of Affliction in Africa and the New World (New York: Garland Publishing, 1982).
} 
population of Iwa between "Rada" and "Petwo" residents of Ville-aux-camps. Less a categorisation of good and bad Iwa, this distinction expresses a complex and subtle ethics of binding power, an ethics which creatively articulates different African retentions within the Caribbean context.

The commonly reported origin of Petwo lies in the exploits of a fugitive from Spanish Santo Domingo called Don Pedro. It is, however, more likely that the name derives from a maroon leader who took the name of a Kongo king. ${ }^{80}$ John Thornton has documented how two conceptions of monarchical power vied for supremacy during the Kongo civil wars that raged between 1665 and 1709 . One narrative of the forging of political order posited a conquering king as the key protagonist, the other posited a reconciliatory king. The latter is exemplified by the legendary Pedro IV who was known for his attempts to unite the warring kingdom between 1694 and $1718 .{ }^{81}$ Nonetheless, both narratives shared the ethical precept that the king had to pursue the common good whether it be through conquering or reconciliation. ${ }^{82}$

Rada references the city of Allada in Dahomey and retains elements of the expansive Fon cultural-political complex which exerted a lasting influence upon Yoruba. ${ }^{83}$ Andrew Apter describes the conduct of spiritual power in Yoruba governance as a tense interplay between the orisha (a Yoruba term consonant with ( $w a$ ) of the royal cult and the lineages of orisha held by the elders who governed various quarters of the kingdom. This governance system ensured that in any one place there existed a mutable relationship between "major" and "minor" orisha depending on who held kingship. Minor orisha might hold more power in peripheral locations, and minor orisha could rise and displace major ones in political struggles. Alternatively, royal cults, representative of cosmic order, were inclusive to the extent that they could - and should - absorb and acculturate minor orisha. ${ }^{84}$

In the Caribbean context, and by the time of Bwa Kayiman, Petwo and Rada have come to articulate a field of mutable power ranging from conquering to reconciliation, and disorder to order, bound by an imperative against genocide. This imperative can be identified in the Petwo concern that both kingly characters (reconciler and conqueror) must pursue the common good and in the Rada concern that no orisha need or should be outcast from the political order when its constellation shifts. Considering the intimate association of slavery with maleficent spiritual science I would suggest that, in the plantation context, this anti-genocidal imperative directly confronts the colonial imperative to dehumanize and desanctify African peoples as things - un-human property of human beings. In short, to be against genocide is to be against slavery.

This, then, is the field that complexly articulates the ethical disposition to bind power through the mediation of I $w a$ and human beings. So, let us imagine once more the cosmogram of the cross. But this time the horizontal plane, which marks the manifest domain, is composed of a pole of conquering and a pole of reconciliation. The vertical plane dives into the cosmic waters where Gine resides. The pole in the waters is one of cosmic order, the other pole that of disorder. The mediation of the Iwa happens where the planes cross. Hence this mediation can be composed of various measures of conquering, reconciliation, order and disorder.

In St Domingue these measures come to inform a new iteration of Rada and Petwo dispositions. Rada Iwa embody the following characteristics: cool, pure, calm, gentle, light, high,

\footnotetext{
${ }^{80}$ Desmangles, "The Christian Cross in Vodun," 111.

${ }^{81}$ Janzen, Lemba, 157; see also Thornton, "King of Congo," 190.

82 Thornton, "King of Congo," 186-191.

83 Desmangles, "The Christian Cross in Vodun," 40; Thornton, Africa and the Africans, 195.

${ }^{84}$ Andrew Apter, "On African Origins: Creolization and Connaissance in Haitian Vodou," American Ethnologist 29, no. 2 (May 1, 2002): 235.
} 
slow and lacking in effective power; while Petwo /wa are hot, fast, hard, tense, terrible, quick, effectively powerful. ${ }^{85}$ Rada Iwa bring knowledge of a deeper esoterica than Petwo /wa, and so are considered closer to Gine and thus to cosmic order. But precisely because of this closeness to Gine, Rada Iwa are often described as cold in the manifest domain: they will only protect you in a passive way, ensuring your survival but not much more. ${ }^{86}$ The knowledge imparted by Petwo Iwa is less esoteric and closer to "magic" - the immediate manipulation of the manifest domain - which itself is closely associated with maleficent spiritual science..$^{87}$ Petwo Iwa enable you to channel cosmic forces in a heated fashion and they can be utilized to expressly manipulate people and matter so as to realize your aim - be it destructive or reconstructive. ${ }^{88}$ The qualities and agencies of Petwo /wa therefore tend - but only tend - towards disorder and/or conquering, while Rada Iwa tend towards order and/or reconciliation.

Rada Iwa are not "good" in and of themselves, but they are considered closer to Gine - the provenance of resanctification, rehumanisation, and reharmonization. ${ }^{89}$ Consonantly, Petwo /wa are not "bad" in and of themselves. But hot power is always more dangerous to mobilize than cool power, even when, as a disordering force, it is put in the service, ultimately, of justice. This is because hot power necessarily promotes the advantage for one individual or group over another and so tends towards maleficent spiritual science. As such, the intentions behind and/or consequences of using hot power open a potential path towards genocidal self-interestedness which, in the St Domingue context, necessarily promotes slavery.

What is more, most families of Iwa are composed of both Rada and Petwo members. Therefore, every cosmic force that the Iwa manifest in the realm of human beings can be mobilized to "cool down" - to serve the reproduction and integrity of existing authority - or to "heat up" - to serve the destruction and transformation of existing authority..$^{90}$ Above all, it is contingent upon the world of human beings whether Gine must be made closer through the mobilization of hot or cold forces, and through conquering or conciliatory means. This is precisely why the ethical moment in Vodou is the mediation of the cosmic powers of the Iwa. Key to this moment is the imperative that, even if required for the pursuit of justice and reconciliation, hot power must be bound (kanga) not to produce genocidal consequences - especially the reproduction of slavery (albeit in different forms).

One way of mobilizing hot power is to fashion a pwen (point). Manifested as an object, or collection of objects bound together (usually including a stone), or even as a kind of spirit, a pwen works towards one's personal advantage and provides an ability to surpass others. ${ }^{91}$ Because such powers infer the pursuit of self-gain, the secretive construction and use of a pwen is often judged to be an act of maleficent spiritual science. Still, a pwen is in and of itself a-moral. ${ }^{92}$ Its transformative powers might, in context, align a group advantage with the pursuit of justice, as is the demand of the god of the Blacks in Boukman's prayer. But the power of a pwen might also escape the control of its users. Hence the imperative to bind - deliver - both white man and enslaved Black peoples from maleficent spiritual science, i.e. the practice of slavery.

\footnotetext{
85 Hurston, "Tell My Horse," 441; McGee, "Constructing Africa," 42.

${ }^{86}$ Larose, "The Meaning of Africa," 115.

87 See Ramsey, The Spirits and the Law, 9; Deren, Divine Horsemen, 75, 200; Hurston, "Tell My Horse," 378; Larose, The Meaning of Africa," 115.

88 Janzen, Lemba, 158-159.

89 See McGee, "Constructing Africa," 42.

90 Apter, “On African Origins," 235; McGee, “Constructing Africa," 42.

91 Larose, "The Meaning of Africa," 160.

92 Ibid., 115.
} 
Those who gather at Bwa Kayiman, under the authority of secret societies, fashion a pwen with which to conquer the genocidal plantation system and deliver a just cosmic order. ${ }^{93}$ Boukman, listening to "the voice of liberty that speaks in all of our hearts", announces that justice must be done on earth (as it is in Gine). Yet justice, here, requires a manipulative power. The thing needs to be heated up. And so Cecile Fatiman undertakes a Petwo ritual. ${ }^{94}$ She sacrifices a black pig for Ezili Kawoulo, the Iwa of secret societies, fierce protector of her people, and righteous avenger of those who refuse her people their humanity. Ezili's chant is one of vengeance, but also of measured justice rather than genocidal self-interest:

If I take a child I'll let him go But if I take an adult, pow-pow

Kawoulo, Kawoulo, If I take an adult... ${ }^{95}$

Ezili takes the place of Cecile's big good angel. The Iwa ride (with) the chiefs to deliver cosmic judgment upon the plantations.

Did the pwen ever finish its work? Were the hot forces bound to cool?

1803. Toussaint L'Ouverture has been spirited away to the Alps and the remaining generals of his army have agreed to abide by French authority. However, the militias, composed principally of maroons and nanchons (African nations), refuse to cede. ${ }^{96}$ Then Napoleon reintroduces slavery into neighbouring Martinique and Guadeloupe. Late in the day, Jean Jacques Dessalines makes common cause between his large army and the militias in order to finally drive out the French. He seals his authority in May by raising a red and blue flag emblazed with the phrase "liberty or death".

There is a commonly rehearsed story of Dessalines ripping the white out of the tricolour to make the new freedom flag. But besides this story of creole creativity is another that speaks to African retentions. For red and blue are actually the colours of the Ogou family of /wa. ${ }^{97}$ The head of this family, Ogou Feray, is the Iwa of war, courage, heroism and also a blacksmith. The blacksmith profession in Kongo cosmology (exemplified by Pedro IV) personifies unselfish conciliation and resolution of conflict. ${ }^{98}$ Interestingly, the Ogou are one of the only families of Iwa who do not demonstrate any clear Petwo manifestations; ${ }^{99}$ their supplication is "fiery rum", which combines both cool (water - Rada) and hot (fire- Petwo) elements. Furthermore, blue is also the colour of Ayizan, female partner to Loco the priest, guardian of the place of one's spiritual birth, protector

\footnotetext{
93 Beauvoir-Dominique and Lùbin, “Investigations Autour Du Site Historique Du Bois Caiman,” 44, 56-58.

${ }^{94}$ On the specifics of Petro sacrifice see Krista White, "Espousing Ezili: Images of a Lwa, Reflections of the Haitian Woman," Journal of Haitian Studies 5/6 (1999): 68; Apter, “On African Origins," 239; Hurston, "Tell My Horse," 444.

${ }^{95}$ A Vodou chant expressing the cosmic force of Ezili Kawoulu. See http://www.plattevalleyreview.org/Webpages/Author\%20Pages/A-K/Beauvoir\%20and\%20Dominique.html

${ }^{96}$ Trouillot, Silencing the Past, 213.

97 Max Beauvoir, "Colors of the Flag," Temple of Yehwe, accessed July 1, 2016, http://www.vodou.org/colors_of_the_flags.htm.

98 Thornton, "King of Congo," 191.

${ }^{99}$ Deren, Divine Horsemen, 135.
} 
against malevolent magic. ${ }^{100}$ Ayizan is another protector of Dessalines, alongside Ogou Feray. ${ }^{101}$ So, in line with the ethical disposition that I have outlined above, I want to argue that Ogou Feray, joined by Ayizan, grant a deeply manipulative power to Dessalines, but one that must be bound by the pursuit of justice and, eventually, reconciliation in a new order.

This disposition informs the Deed of Independence within which Dessalines compels his generals to commit to freedom or death. ${ }^{102}$ The Deed is addressed to the "native army", a term that references the long and living history of indigenous/enslaved marronage. As Jean Casimir argues, ${ }^{103}$ the organizing principle of being indigène works other-wise to colonial science by proposing a quotidian living together - a seminal relationality, rather than the genocidal segregation of plantation slavery. Dessalines' Deed therefore announces an independence that is other-wise to the racialized schemas of French massa, as the empire of liberty takes a Taino name - Ayiti.

The principle of indigène is implicated in article 14 of Dessalines' 1805 Constitution whereby all Haitians are given the appellation noir. I would argue that noir is indigène legally codified as a replacement to the colonial Code Noir. This interpretation is given weight by the fact that, as Siba Grovogui notes, the only proscription of residence in Dessalines' constitution (article 12) references the kind that disavows relationality and quotidian living together, i.e. genocidal white property ownership. Moreover, even this proscription is not essentially racialized as it exempts (in article 13) white women and their children who, left without their men and their men's property, would therefore require protection under the constitution. ${ }^{104}$

Yet despite all of this, and as Anne Gulick perceptively argues, the "we" of Dessalines' Constitution does not articulate a unified "peoples" but instead marks a distinction between a few named leaders - the authors of the document - and the masses. ${ }^{105}$ The quotidian relationality of noir/indigène disappears in the actual authorship of the constitution. There is no living together when it comes to the relationship between ruler and ruled. Why is there this distressing separation? Less a claim on absolute power, I suspect that Dessalines is trying to bind (kanga) his own hot power.

Intent upon exorcising the French from St Domingue, Dessalines must in 1803 inherit - or take - the pwen fashioned at Bwa Kayiman in 1791. A re-concentration of power is crucial. Not only have significant divisions become entrenched amongst the various populations and fighting forces of the enslaved, but in in the intervening years Haiti has become geopolitically encircled by slaveholding forces. Facing such a threat Dessalines (as did Toussaint) must uphold a militarized plantation system that, by force, ties (now) formally free peoples back to the sites of their French enslavement, there to produce crops to be sold for weapons for defence against the slaveholding

\footnotetext{
100 Ibid., 148.

101 Bellegarde-Smith, "The Spirit of the Thing," 64.

102 On Dessalines' authorship of the various deeds and declarations see Deborah Jenson, "Dessalines's American Proclamations of the Haitian Independence," The Journal of Haitian Studies 15, no. 1 (2009): 72-102.

103 See especially Casimir, "Haïti et Ses élites."

104 Siba N. Grovogui, "To the Orphaned, Dispossessed, and Illegitimate Children: Human Rights Beyond Republican and Liberal Traditions," Indiana Journal of Global Legal Studies 18, no. 1 (2011): 41-63.

105 "We Are Not the People: The 1805 Haitian Constitution's Challenge to Political Legibility in the Age of Revolution," American Literature 78, no. 4 (2006): 799-820.
} 
powers. ${ }^{106}$ That the whip has been replaced by tough vine and heavy cane only speaks to the terrible compromise of this moment. ${ }^{107}$

It is telling, in this regard, that the imperial flag that Dessalines provides in article 20 of the first Constitution is no longer blue and red but black and red, a colour combination that represents secret societies. ${ }^{108}$ Not that secret societies are essentially purveyors of maleficent spiritual science. Nonetheless, the reconciliatory nature of Ogou Feray and the protection against malevolent magic granted by Ayizan are qualities now notable for their absence. The flag announces Dessalines as more of a conqueror than a reconciler, or at the very least, one who concentrates all the power to his own advantage.

Is the Constitution, therefore, a maleficent document? After all, the geopolitical context has compelled Dessalines to concentrate his power by visiting slavery-like genocidal-like exploitation of his peoples. But no. While the Constitution is most certainly an expression of Dessalines' power, it is also a binding document. The Constitution is intended to bind (kanga) Dessalines' power by establishing a space of living together (noir/indigène) for the masses while at the same time removing that space from the authorship of the Emperor and his generals. What other legal document in the age of revolutions exhibits such pragmatism and principle?

Regardless, in the scramble to advance their individual positions other generals soon conspire to Dessalines' murder in October 1806. Perhaps they are in competition over ownership of the pwen inherited from Bwa Kayiman. In any case, the thing heats up even more. Later constitutions start to re-introduce genocidal principles. Article 14, the constitutionalising of noir/indigene, does not survive Dessalines' constitution. ${ }^{109}$ In fact, the principle of living together - of seminal relationality - subsequently becomes embedded in the lakou model of co-operative land management based on extended family relations, a model that confronts an increasingly predatory state. ${ }^{110}$ Yet even the lakou model comes under threat of disintegration when the 1918 constitution, authored under US occupation, dispenses with the censure against white property ownership, thereby paving the way for imperial land grabs. Railing against the indignity of white occupation, François Duvalier's regime resurrects the black and red flag of Jean Jacques Dessalines only to proceed to kill Haitians with impunity through a secret society known as the Tonton Makout.

More conflagration, more US-authored interventions, and now Protestant missionaries (beloved of Hegel) arrive, seeking to destroy the very archaeological remnants of Bwa Kayiman where Haiti made a "pact" with the "devil". ${ }^{111}$ But let us be understanding towards these evangelicals of world spirit. The devil is real only because the Iwa still live and are still called forth, for example, in a traditional song that resonates defiantly across the Haitian countryside:

Sanble Iwa yo

\footnotetext{
106 Shilliam, "What the Haitian Revolution Might Tell Us," 793-797.

107 M. Lundhal, "Defense and Distribution: Agricultural Policy in Haiti During the Reign of Jean-Jacques Dessalines, 1804-6," in In Politics or Markets? Essays on Haitian Underdevelopment (London: Routledge, 1992), 184.

108 See Beauvoir-Dominique, "Reclaiming Indigenous Heritage."

${ }^{109}$ Sibylle Fischer, Modernity Disavowed: Haiti and the Cultures of Slavery in the Age of Revolution (Durham: Duke University Press, 2004), 235.

${ }^{110}$ See in general, Serge Larose, "The Haitian Lakou: Land, Family and Ritual", in A. F. Marks \& R. A. Römer (eds.), Family and Kinship in Middle America and the Caribbean (Curaçao: Institute of Higher Studies, 1975), pp.482-512.

${ }^{111}$ Not all Black protestantisms have been opposed to the Revolution; see Alanna Lockward, Allen Report: Retracing Transnational African Methodism, 2016.
} 
Nan Bwa Kayiman nou ye Nou tande fizi tire

Apre Bondye

Se nou se'l ki chèf la ye

Apre Bondye

Se nou chef

We have travelled far from CLR's Francophile/phobe dramaturgy. Past the angst of creole creativity - blank landscapes and bodies - our journey has taken us through seminal relations, living African and indigenous retentions, and from Ville-aux-Camps - the city of /wa under the cosmic waters - to the imperial geopolitics of the manifest domain. Nonetheless I am sure that much of what you have read will have resonated with your existing apprehensions of the cosmos. You might have recognized comforting elements of cosmopolitan, communitarian and anarchistic ethics. Or felt, thank Bondye, a proper dialectics casting its subterranean magic. Sensed, even, a Machiavellian or Weberian critique of power. Perhaps you gleaned a north-eastern future in this Caribbean past, gesturing towards a critique of Weimar constitutions and fascist revolutions. But then again, why would we presume that we could not connect with Bwa Kayiman - somehow, somewhere? After all, the Iwa are not super-natural, they are other-wise.

If the Iwa were not gathered at Bwa Kayiman with the chiefs, then there would have been no revolution. I am making an eminently pragmatic point. What moved the people to revolt? In Vodou, the Kreyol word konesans infers knowledge, insight and overstanding gifted by the Iwa and cultivated through experience. What did the people know, not merely believe? The question cannot be adequately answered ex post facto through the deliverance provided by a division of labour, false consciousness, the sovereign subject, psychoanalytical transference or even ideology. If the people did not know that the Iwa were riding (with) them to burn down the plantations, then they would not have moved their feet. The Iwa are agents of international relations.

Could you work within or with this other-wise? Or can you at least acknowledge its explanatory adequacy without feeling that you have sacrificed your intellectual integrity? I myself do not serve the Iwa although I do wish to know them better. Hence I recognize how difficult it is to sincerely place the I $w a$ in a quotidian, unexceptional fashion alongside the elements of colonial science. Nevertheless, these difficulties are not the fault of the Iwa; they are the burden of race that hangs upon our frameworks. Race: that which creates the profane and reasonable in opposition to the mystic and primitive; carves out a supernatural black in distinction to a real (Christian) white; faces humans in opposition to less-than-human natives and negroes; at its most generous, that which pastes together a "creole" from natives and negroes - a hollowed out blank subject waiting for animation. But that there are living retentions from the African continent in league with the peoples of the land? And that these retentions are seminal to the making of the most radical of all revolutions that inaugurate our present world order?

This is why the meeting at Bwa Kayiman is everything to do with race and nothing to do with race. Race is the schema that demands the meeting. But the response is not of the same schema. Critiquing race only through its own schema is a fundamental failure of our politics and imagination. In doing so we are silencing the response. In the midst of enslavement, of not simply exploitation or oppression but radical dehumanization and desanctification, literally genocide, shackled stripped and whipped, the sufferers still remain concerned that their mediation of cosmic forces must be 
bound by the imperatives of justice for all. Meanwhile, another Jean Jacques - Rousseau - writes that man is born free but everywhere lives in metaphorical chains.

Compare.

Might those who broke the physical chains have something valuable to say about presentday struggles over global justice? Is it intellectually satisfying to consider anything less? 